\title{
Landforms and Coastal Retreat in Relation to Thawing of "Edoma" on Southern Coast of Bolshoi Lyakhovsky Island, Northeastern Siberia
}

\author{
Kiyoshi SAIJo*, Daisuke NAGAoKA** and Masami FukudA*** \\ *Faculty of Education, Miyagi University of Education, \\ Aoba, Sendai, 980-0845, Japan \\ **Raax Co., Ltd., 1-12, Kita-24, Higashi-17, Higashi-ku, Sapporo, 065-0024, Japan \\ ***Institute of Low Temperature Science, Hokkaido University, \\ Kita, Sapporo, 060-0819, Japan
}

\begin{abstract}
The characteristics of landforms and coastal retreat resulting from thawing of permafrost called "edoma", which is widely distributed along the Arctic coast in northeastern Siberia, are discussed. Edoma is composed of massive ground ice containing evenly scattered frozen soil pillars, and underlain by ice-poor silty sediments. The meteorological data at some adjacent locations indicate that thawing is active from mid June to mid September. Four landform units: upper flat, upper cliff, middle gentle slope, and lower cliff, are recognized from inland to seaside near the coastline on which edoma is exposed. Upper flat roughly corresponds with the top of the edoma, while many mounds formed by thermokarst subsidence are scattered on it. Thawing of edoma is extremely active on the upper cliff, and consequently the cliff itself retreats. Although much microtopography indicating active thawing of edoma is widespread on the middle gentle slope, downward thermal erosion seems to become ineffective in the lower horizon of edoma because the underlayer of edoma consists of ice-poor silt which does not suffer considerable morphological change by thawing. The lower cliff which directly faces the sea is exposed to thermal erosion by waves, and a notch is successively formed at the base. Sudden coastal retreat amounting to several meters is expected after the notch becomes deep enough to collapse. These processes are controlled by the characteristics of material, structure, and stratigraphy of the permafrost in this area.
\end{abstract}

Key words: Siberia, permafrost, Edoma, coastal retreat, landform classification

\section{Introduction}

Coastal processes on shorelines around the Arctic Ocean have some unique characteristics being quite different from those in nonperiglacial regions mainly because of sea ice and permafrost. Sea ice usually plays the role of reducing wave action, and thermal erosion frequently leads to peculiar coastal evolution on shorelines composed of permafrost (Hill et al. 1994; French 1996). The actual state of coastal processes in the Arctic region, however, is not simple but various, corresponding to sitespecific factors such as ice cover and geological setting. In addition, data on coastal landforms and processes in this remote region are still not enough as the result of difficulty in data collec- tion work (Hill et al. 1994). These points require further detailed case studies in many locations under different kinds of conditions.

Where permafrost on shorelines is composed of unconsolidated and ice-rich sediments, rapid and dramatic coastal retreat takes place due to thermal erosion (French 1996: 212). Such a type of permafrost is distributed along the Alaskan and Canadian Beaufort coast and northeastern Siberia (Hill et al. 1994). Many studies about rapid coastal retreat occurring on the Alaskan and Canadian Beaufort coast have been presented (Hume et al. 1972; Mackay 1986; Shimizu and Fujino 1987).

A similar kind of permafrost composed of massive ground ice with frozen silty soil pillars is distributed in northeastern Siberia. This unique permafrost is named "edoma" which 


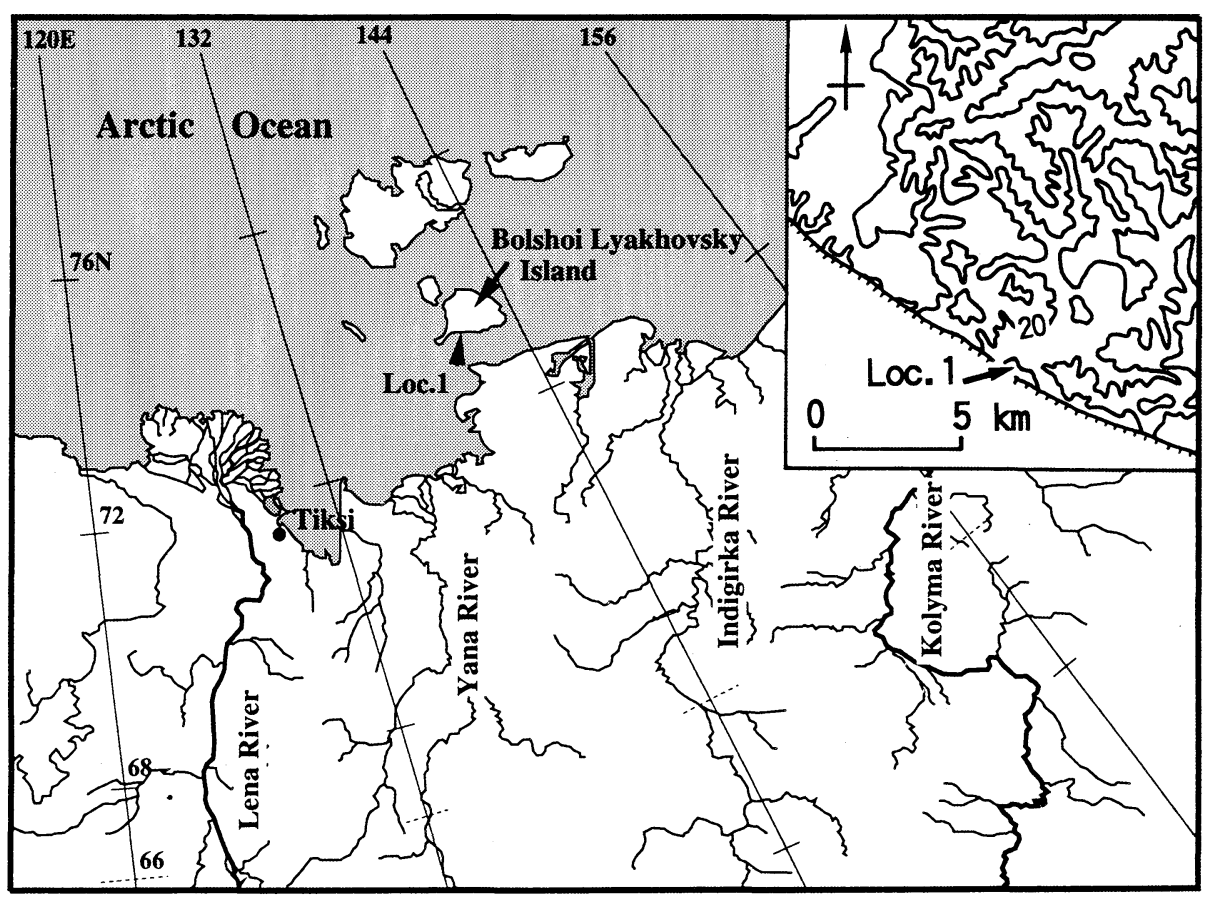

Figure 1. Study area.

Contour lines in small box are drawn at intervals of $20 \mathrm{~m}$.

means "corroding land" in the local language. Several former studies suggest that edoma was formed as the result of the growth of syngenetic ice-wedge (Popov 1969; Sone 1994) mainly during the last glacial stage (Kaplina and Lozhkin 1984; Nagaoka et al. 1996). The above meaning of the word "edoma" indicates that edoma is suffering a rapid geomorphic change. In fact, coastal retreat at the rate of several meters per year is recognized along the Laptev Sea (Are 1972). Consequently some islands which certainly existed in the 19 th century have been disappearing in this region (Barr 1976). Nevertheless, the detailed processes of coastal retreat in relation to the thawing of edoma are not fully elucidated, because the description about the processes has tended to be too general in previous studies. Although Czudek and Demek (1970) introduced some detailed case studies on thermokarst in Siberia, examples on shorelines are few. Therefore, more studies should be carried out. In particular, description of geomorphic changes in microtopographical scale and visual data such as photographs and figures are necessary.
This paper reports on the geomorphic processes of coastal retreat that resulted from thawing of edoma on the southern coast of Bolshoi Lyakhovsky Island in northeast Siberia (Figs. 1 and 2). The surrounding area including the study site belongs to continuous permafrost zone, and edoma is widespread. The bottom of the permafrost at Tiksi exsits at a depth of 650 m (Katasonov and Solov'ev 1969). The mean annual temperature in 1967 at Tiksi was $-13.4^{\circ} \mathrm{C}$, and the mean monthly temperature exceeded $0{ }^{\circ} \mathrm{C}$ from June to September (Kunitsky 1989). According to measurements from August of 1992 to July of 1994 at Kalakhari Island near Tiksi, ground temperature at a depth of $20 \mathrm{~cm}$, as well as air temperature, were higher than $0^{\circ} \mathrm{C}$ from the middle of June to the middle of September (Nakayama 1995). These meteorological data suggest that thawing of edoma is active in those months. Observation of the landforms and geomorphic processes by the authors was carried out from August 5th to 19 th in 1993; and from August 20th to 25th in 1994, respectively. Although the observation period was quite short, it is expected that some 


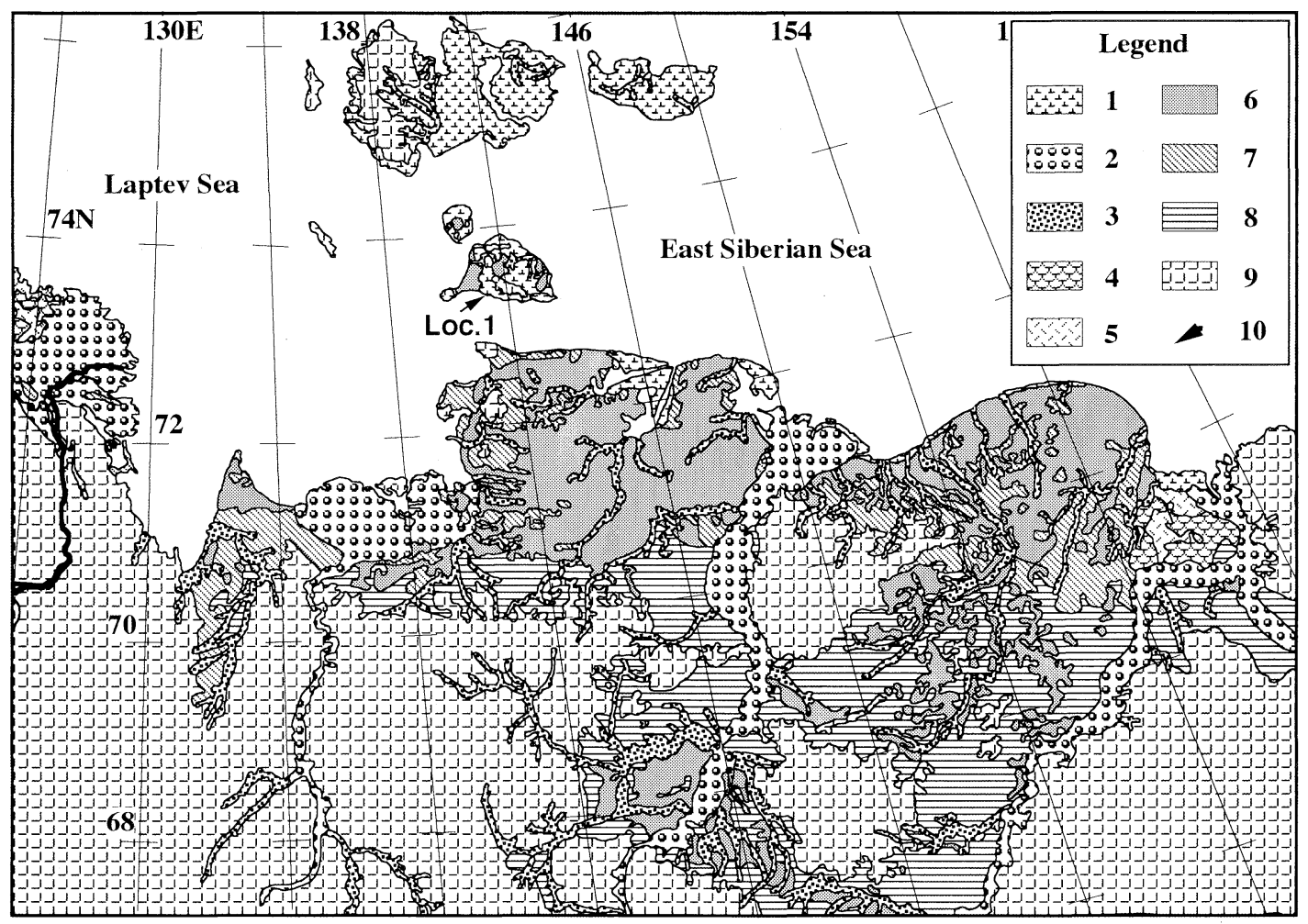

Figure 2. Distribution of landforms in northeastern Siberia.

1: Shore 2: River bed 3: Valley plain 4: Sand dune 5: Interdune lowland 6: Thermokarst 7: Interthermokarst (tundra region) 8: Interthermokarst (taiga region) 9: Mountain \& mountain slope 10: Location Modified from Melnikov (1991).

This legend is translated from Russian into English by the authors.

important features on coastal evolution in this region could be detected because the period was set in the middle of the months when the thawing of edoma is active.

\section{Observation of Landforms and Geomorphic Change}

The selected site (Loc. 1, Fig. 1) is one of the few places where edoma and its underlayer are exposed. Although both of them consist of unconsolidated sediments, they are materially and structurally different. Edoma is massive ground ice with evenly distributed silty soil pillars. Its ice content amounts to 85 to $93 \%$ (Tomirdiaro 1982). On the other hand, the underlayer of edoma is composed of ice-poor silt. Such characteristics of each type of permafrost seem to produce different reactive geomorphic processes to thawing. Consequently it has been suggested that Loc. 1 is suitable for investigat- ing the relationship between different types of permafrost and geomorphic changes caused by thermal erosion. The following description is therefore based mainly on the observation at Loc. 1, while some photos taken at the other locations within the area in Fig. 1 are employed in Figs. 4, 7, 9, and 10 to clarify the explanation.

The top of the edoma at Loc. 1 provides a flat geomorphic surface at the height of about $30 \mathrm{~m}$ a.s.l. (Figs. 3 and 11) This geomorphic surface faces seaward with a stepped slope composed of two levels of cliffs and a gently sloping section between them. On the basis of this characteristic, the topographic section perpendicular to the coastline is divided into four landform units, namely: "upper flat", "upper cliff", "middle gentle slope", and "lower cliff" from inland to seaside (Figs. 3 and 11). Such composition of the landform units was similar both in 1993 and 1994. The upper cliff has a steep slope of more than 70 degrees, and its height is about 15 


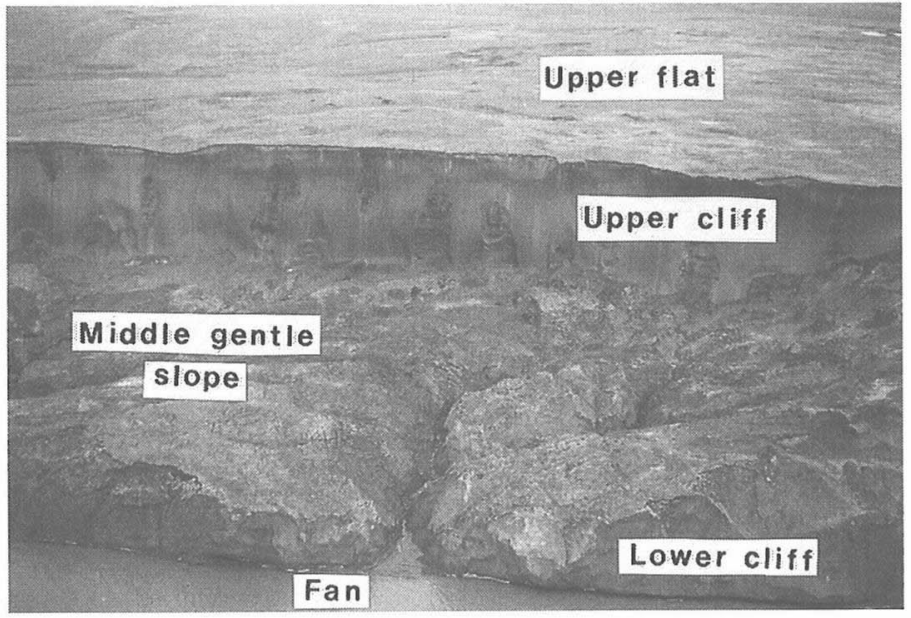

Figure 3. Landform units observed at Loc. 1 on the southern coast of Bolshoi Lyakhovsky Island. The relative height of upper cliff is about $15 \mathrm{~m}$.

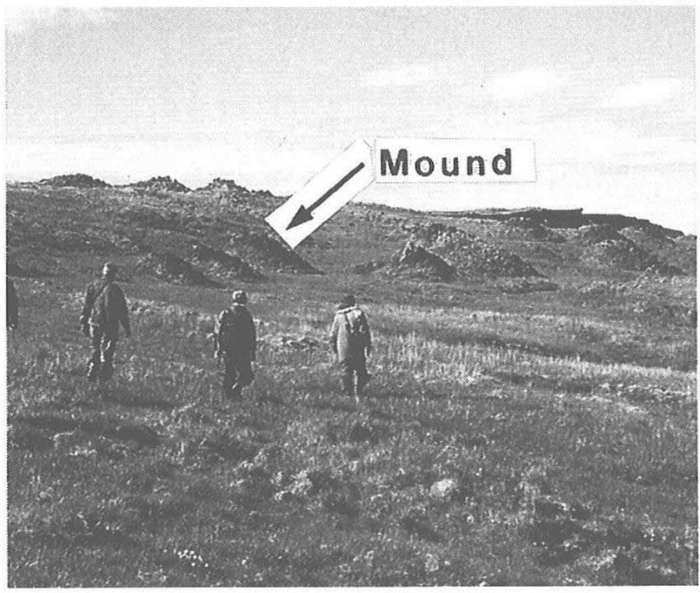

Figure 4. Mounds (edoma sediments) on upper flat.

m. The lower cliff also has a steep wall, while its relative height is 4 to $10 \mathrm{~m}$. The gentle part between the upper and lower cliffs is middle gentle slope. The horizontal distance between the uppermost and lowermost points of the middle gentle slope is about $50 \mathrm{~m}$. The remarkable geomorphic changes recognized during the above observational period and some characteristic microtopography on these landform units are described below.

Many dome-like mounds, most of which have a diameter about 3 to $4 \mathrm{~m}$ and a height of about $1 \mathrm{~m}$, are scattered on the ground surface of the upper flat (Fig. 4). They are composed of previ-

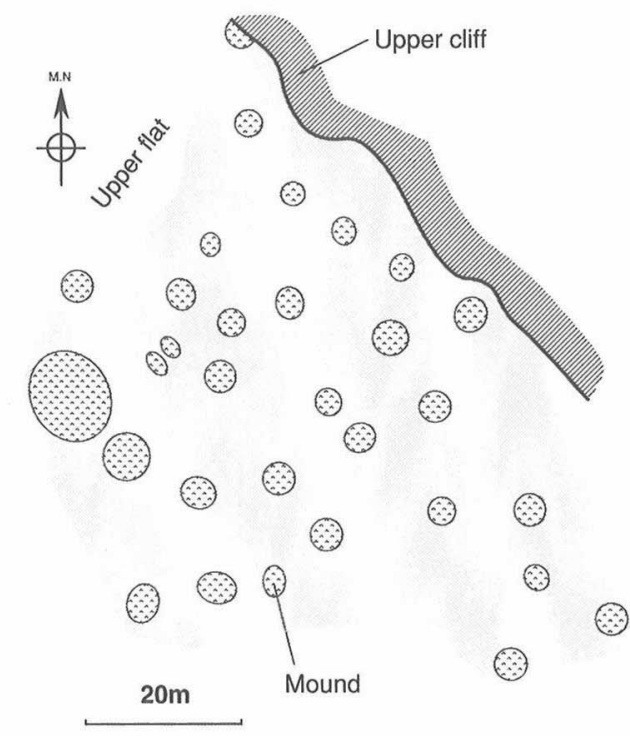

Figure 5. Distribution of the mounds on upper flat drawn by plane table surveying.

ously mentioned frozen soil pillars. Figure 5 shows an example of the distribution of the mounds at Loc. 1 surveyed on Aug. 11, 1993. It is estimated that thermokarst subsidence is more effective on ground ice than on frozen soil. A smaller sinking rate is consequently expected at the place underlain by frozen soil. Such uneven subsidence of the ground surface results in the appearance of the mounds on the upper flat.

The vertical section of the edoma can be seen 


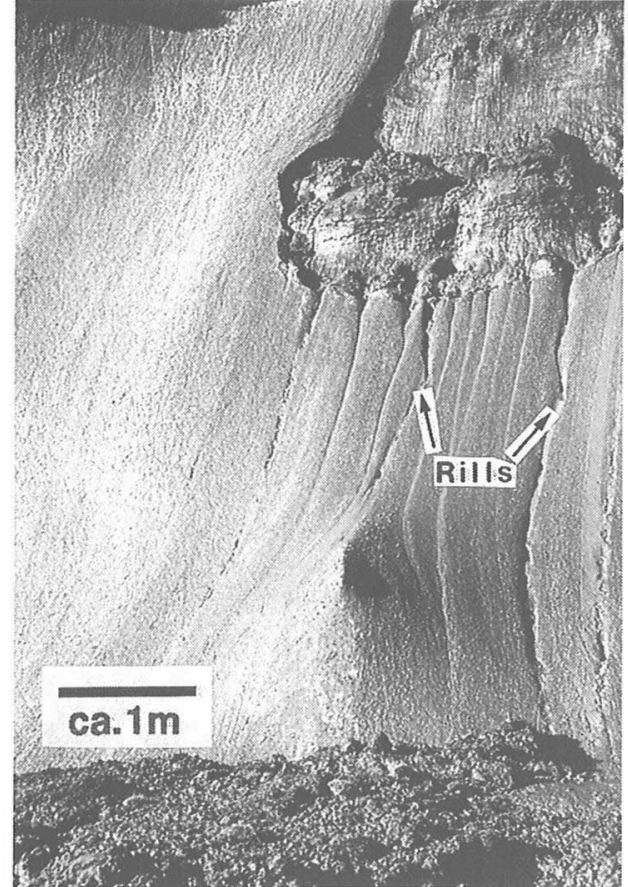

Figure 6. Rills formed by melt water on the surface of upper cliff.

on the surface of the upper cliff. Thawing of edoma occurs very rapidly on this section especially in the daytime because of solar radiation and rising temperature. The melt water flowing down often leaves rills on the surface of the cliff (Fig. 6). As a result of the thawing of edoma, the active layer above the edoma overhangs, falls down frequently, and the marginal line of the cliff finally retreats (Fig. 7). A large accumulation of the fallen active layer at the foot of the upper cliff indicates that this process is frequent. Actually, the falling of the active layer was directly observed several times even in a few hours at the same place. A similar kind of retreating cliff has been reported at the Mackenzie Delta in Arctic Canada (Mackay 1966; Shimizu and Fujino 1987).

The results of measurements of coastal retreat from 1955 to 1958, on the south coast of Bolshoi Lyakhovsky Island, show rates of between 2 to $30 \mathrm{~m}$ per year (Barr 1976). Although the authors themselves did not carry out any systematic measurement of retreat rate of the upper cliff, the following fact was recognized. The hole, which was dug on August 8th of 1993

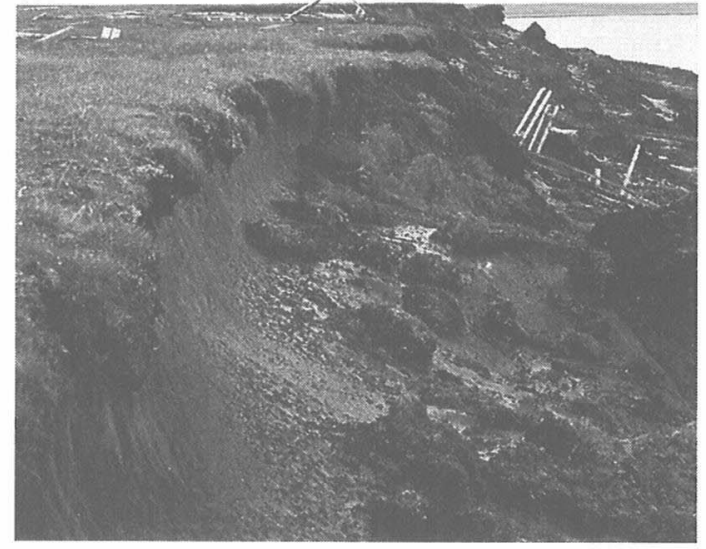

Figure 7. Overhanging of active layer and following retreat of the cliff.

A large accumulation of the fallen active layer indicates the activeness of this process.

for work at a point located about $5 \mathrm{~m}$ landward from the edge of the upper flat, almost disappeared by the time of field work in 1994. This suggests that the retreat rate of the upper cliff is approximately $5 \mathrm{~m}$ per year. In addition, one of our Russian co-researchers who has measured the retreat rate of the upper cliff near Loc. 1 during the past several years also indicates rates ranging from $3.5 \mathrm{~m}$ to $5.1 \mathrm{~m}$ per year (Grigoryev, M. N. personal com.). These facts suggest that the upper cliff retreats at the rate of several meters per year, in general.

The middle gentle slope inclines at about 5 to 10 degrees seaward as a whole, though its surface is not smooth but rather undulating due to the existence of baidzharakhi (Fig. 8) and small stream channels. Baidzharakhi are conical mounds composed of frozen soil in edoma. Fluid mud produced by thawing of edoma covers a large part of the middle gentle slope, and a small scale mudflow occurs in places. As a result, most parts of the middle gentle slope are extremely muddy. Although edoma ice is not commonly recognized on the middle gentle slope, it is preserved by a covering of mud in some places. A concentration of melt water leads to stream channel formation, and mud transported by the stream forms a small fan at the mouth of the stream (Figs. 3 and 11). These geomorphic processes on the middle gentle 


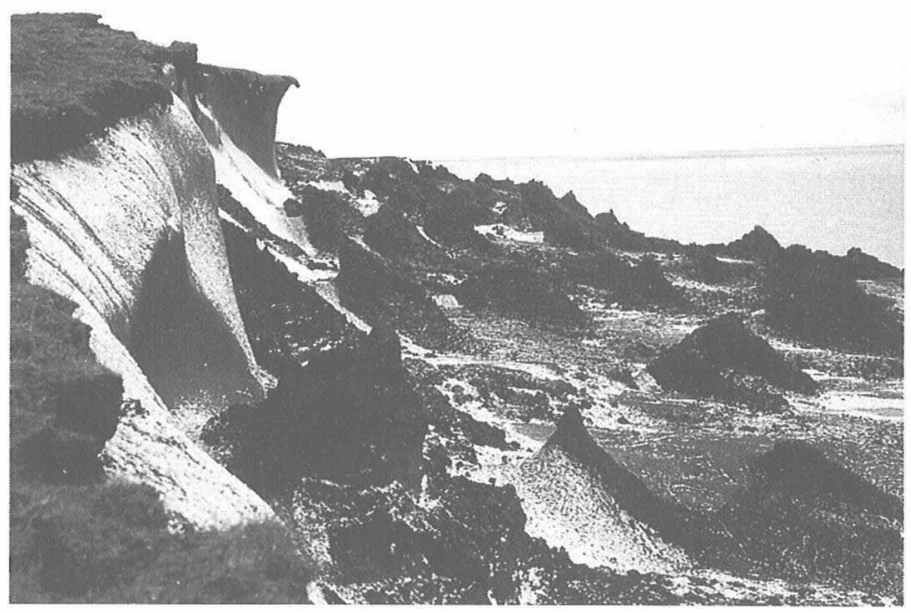

Figure 8. Upper cliff and baidzharakhi on middle gentle slope. The relative height of the upper cliff is about $15 \mathrm{~m}$.

slope are similar to those at the "thermocirque floor" as identified by Czudek and Demek (1970).

The middle gentle slope which has an altitude of between 4 and $15 \mathrm{~m}$ seems to indicate that the lowering of ground surface due to thermal erosion does not progress down to sea level but stops or decelerates halfway. According to Nagaoka et al. (1996), the lower boundary of edoma exists at about $4 \mathrm{~m}$ a.s.l. at Loc. 1. It means that the level of the middle gentle slope corresponds to the lower part of the edoma. These points may suggest that some kind of base level of thermal erosion exists below the lower part of the edoma. The underlayer of edoma is thought to be less subject to morphological change by thawing because it does not contain much ice. It is estimated that the underlayer plays an important role in reducing downward thermal erosion and the middle gentle slope is consequently formed. The difference in height between the middle gentle slope and the top of the underlayer is maintained by the remnant of edoma.

The middle gentle slope faces the sea with lower cliff on which the underlayer of edoma is exposed. Because this cliff falls directly to sea level, a notch (thermo-erosional niche) is formed at the base of the cliff as the result of thermal erosion by waves (Fig. 9). In cases when the notch erodes the cliff very deeply, the overhanging part may finally collapse. Although

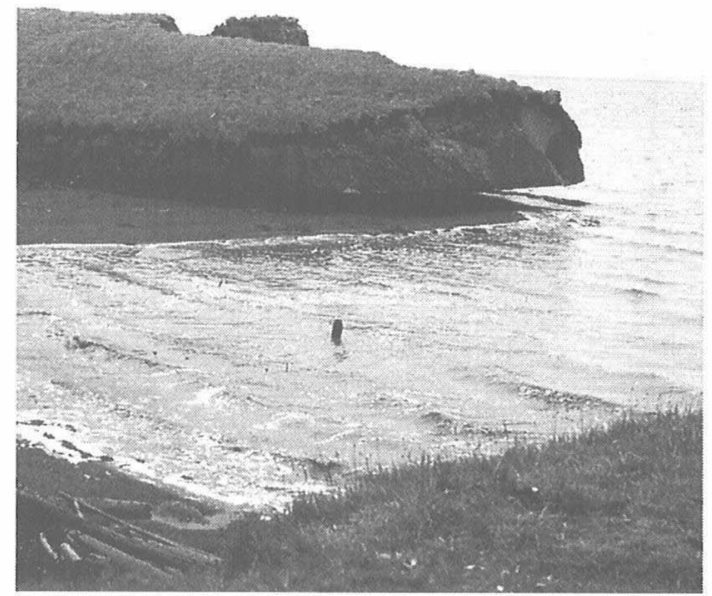

Figure 9. Notch formed by thermal erosion by waves.

the authors did not see the collapse of the notch at Loc. 1, large blocks produced by the failure of an overgrown notch were observed in the vicinity (Fig. 10). It is estimated that retreat rate of the lower cliff at least amounts to several meters per one collapsible event, judging from the depth of notch and sizes of the collapsed blocks. Although the retreat of the lower cliff temporarily leads to a reduction of the middle gentle slope, its area may be kept almost constant for a 


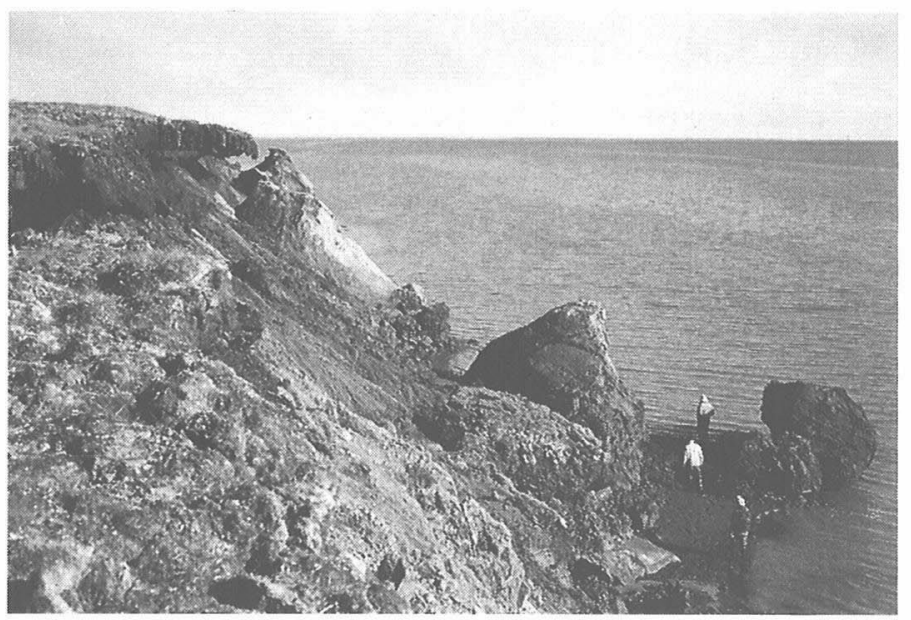

Figure 10. Large blocks of collapsed permafrost observed at the coast located several hundreds meters eastwards from Loc. 1 .

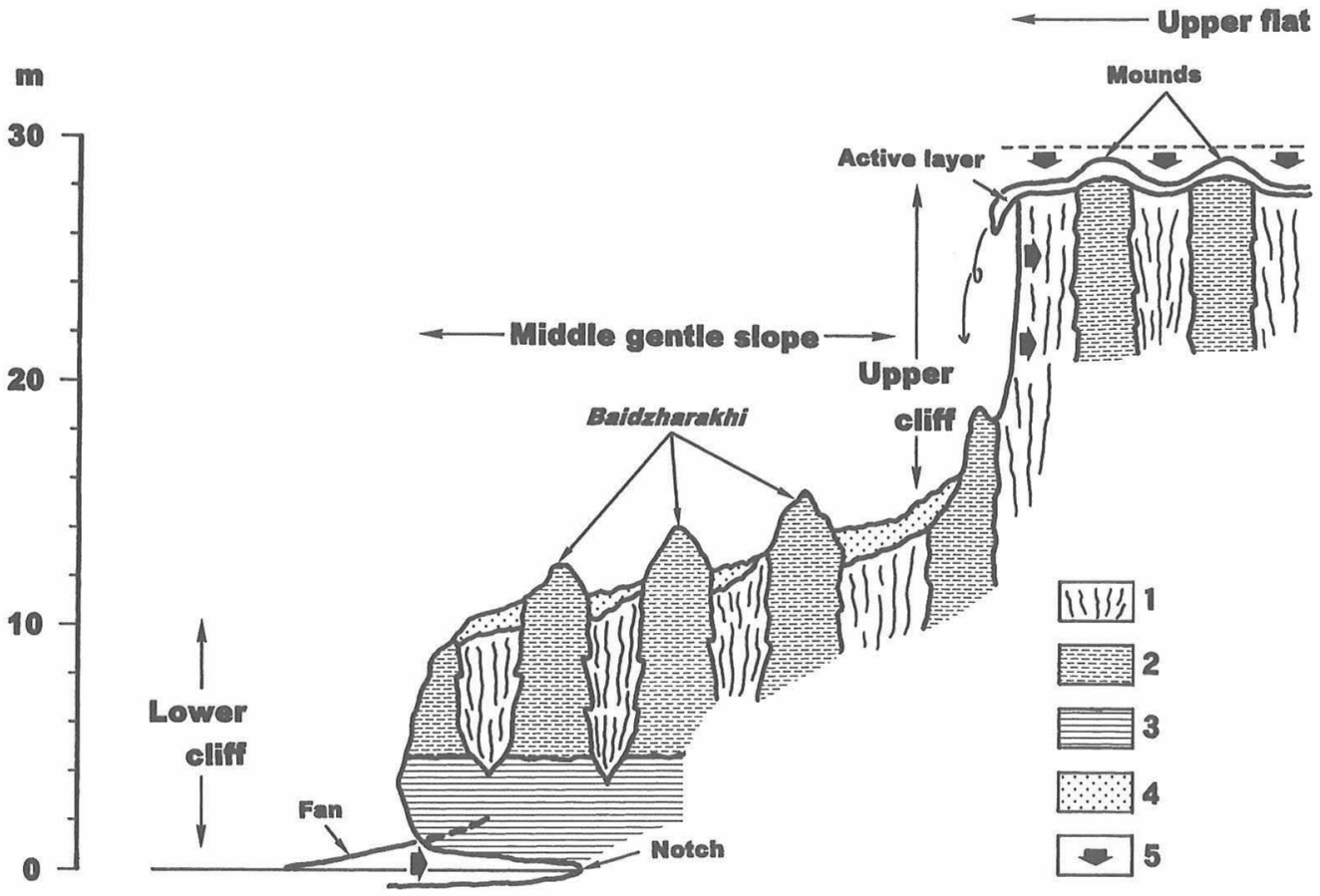

Figure 11. Schematic geomorphic profile across the coast.

1: Ground ice (edoma), 2: Frozen soil (edoma), 3: Ice-poor silt (underlayer of edoma), 4: Mud, 5: Thermal erosion

year-long period because the upper cliff also retreats at the above-mentioned rate.

These are the landforms, geomorphic changes, microtopography, and their distribution which resulted from the thawing of edoma near the coastline. They are schematically illustrated in Fig. 11.

\section{Discussion}

The geomorphic processes caused by the thawing of edoma are producing some characteristic landform units and microtopography, and are probably resulting in coastal retreat at 
the rate of several meters per year. So far as the authors have observed, the composition of the landform units have appeared to be unchanged between 1993 and 1994, in spite of the rather rapid coastal retreat, probably because the retreat rates of upper and lower cliffs were more or less of the same order.

However, the results of this study are not always applicable to all coasts where edoma is exposed. For example, the middle gentle slope may not be formed in cases where the boundary between the edoma and its underlayer exists below sea level. In this situation, the coastal cliff suffers two kinds of erosional processes: thawing of edoma itself and thermal erosion by waves. Some previous studies indicate that different forms of coasts can be recognized within northeast Siberia (Are 1972). Such differences in coastal type may reflect differences in material composition, structure, and stratigraphy of permafrost at each site. In addition, the shortness of the observational period sets a limit for the estimation of geomorphic changes over a longer time scale. Furthermore, there are many other controlling factors of coastal evolution, such as direction of coast and sea ice conditions. These factors are not considered in this study due to lack of data. Further case studies at different places and observation over a longer period of time are necessary.

\section{Conclusion}

Landforms and geomorphic changes that resulted from the thawing of edoma during the summer season were observed at a coastal location in northeastern Siberia. The major results are as follows:

Landforms near the coastline can be divided into four units: upper flat, upper cliff, middle gentle slope, and lower cliff from inland to seaside. Each unit is characterized by unique geomorphic changes and some microtopography. These landforms and geomorphic changes are closely related to thawing processes which are controlled by material, sedimentary structure, and stratigraphy of the permafrost. Geomorphic changes during the summer season are drastic, and rapid coastal retreat seems to take place at this time. It is estimated that both the upper and lower cliffs retreat at rates of several meters per year, although the actual geomorphic processes causing the retreat of each cliff are different. The upper cliff retreats due to thawing of edoma itself, and the lower cliff does so as the result of collapse of overgrown notch formed by thermal erosion.

\section{Acknowledgement}

This study was supported by the Ministry of Education, Science, and Culture, Japan as the Grants for International Scientific Researches, "Climatic influences to cryosphere-biosphere in Siberian permafrost" (Headed by Masami Fukuda, No. 64041014). We express our sincerest gratitude to Dr. V. V. Kunitsky of the Permafrost Institute, Siberian Branch, Russian Academy of Science, Yakutsk, Professor A. A. Alkhangerov of the Department of Cryolithology and Glaciology, Faculty of Geography, Moscow State University, and the members of our joint expedition.

(Received Jul. 23, 1999)

(Accepted Nov. 1, 1999)

\section{References}

Are, F. 1972. The reworking of shores in the permafrost zone. In International geography, ed. W. P. Adams and F. Helleiner, 78-79. Toronto: University of Toronto Press.

Barr, W. 1976. Retreating coasts and disappearing islands in the Arctic. Musk-Ox 18: 103-111.

Czudek, T., and Demek, J. 1970. Thermokarst in Siberia and its influences on the development of lowland relief. Quaternary Research 1: 103-120.

French, H. M. 1996. The Periglacial environment. London: Longman.

Hill, P. R., Barnes, P. W., Héquette, A., and Ruz, M-H. 1994. Arctic coastal plain shorelines. In Coastal evolution, ed. R. W. G. Carter and C. D. Woodroffe, 341-372. Cambridge: Cambridge University Press.

Hume, J. D., Schalk, M., and Hume, P. W. 1972. Shortterm climate changes and coastal erosion, Barrow, Alaska. Arctic 25: 272-278.

Kaplina, T. N., and Lozhkin, A. V. 1984. Age and history of accumulation of the "Ice Complex" of the maritime lowlands of Yakutiya. In Late Quaternary Environments of the Soviet Union, ed. A. A. Velichiko, 147-151. Minneapolis: University of Minnesota Press.

Katasonov, E. M., and Solov'ev, P. A. 1969. Guide to trip round central Yakutia. International Symposium Paleogeography and Periglacial Phenomena of Pleistocene, Yakutsk.

Kunitsky, V. V. 1989. Cryolithology in estuary of the Lena. Academy of Science, USSR, Yakutsk, (in 
Russian)

Mackay, J. R. 1966. Segregated epigenetic ice and slumps in permafrost, Mackenzie Delta area, N.W. T. Geographical Bulletin 8: 59-80.

Mackay, J. R. 1986. Fifty years (1935-1985) of coastal retreat west of Tuktoyaktuk, District of Mackenzie. Geological Survey of Canada, Paper 86-1A, 727-735.

Melnikov, P. I. 1991. Permafrost-landform map. Yakutia Autonomous Soviet Social Republic. (in Russian)

Nagaoka, D., Saijo, K., Fukuda, M., and Nakamura, T. 1996. Paleoenvironment and period of the "Edoma" formation in high Arctic eastern Siberia. Journal of Geography 105: 15-30. (JE)

Nakayama, T. 1995. Estimation of methane emission from natural wetlands in Siberian permafrost area. Ph. D. Dissertation, Institute of Low Temperature Science, Hokkaido University.
Popov, A. I. 1969. Underground ice in the Quaternary deposits of the Yana-Indigirka lowlands as a genetic and stratigraphic indicator. In The Periglacial environment ed. T. L. Péwé, 55-64. Montreal: McGill-Queen's University Press.

Shimizu, O., and Fujino, K. 1987. Thermal erosion on the coastal slope of an involuted hill in Mackenzie Delta, Canadian Arctic. Transactions Japanese Geomorphological Union 8: 21-32.

Sone, T. 1994. Origin of the ice-complex in the Bykovsky Peninsula, East Siberia. In Proceedings of the Second Symposium on the Joint Siberian Permafrost Studies between Japan and Russia in 1993, ed. G. Inoue, 19-21. Tsukuba.

Tomirdiaro, S. V. 1982. Evolution of lowland landscape in northeastern Asia during late Quaternary time. In Paleoecology of Beringia, ed. D. M. Hopkins, 29-37. New York: Academic Press. 